\title{
Effects of Mobile Augmented Reality (MAR) towards Students' Visualization Skills when Learning Orthographic Projection
}

\author{
https://doi.org/10.3991/ijet.v14i20.11463 \\ Marlissa Omar, Dayana Farzeeha Ali ${ }^{(凶)}$, Mahani Mokhtar, \\ Norasykin Mohd Zaid, Hanifah Jambari, Nor Hasniza Ibrahim \\ Universiti Teknologi Malaysia, Skudai, Malaysia \\ dayanafarzeeha@utm.my
}

\begin{abstract}
Recent study shows an increasing interest towards the implementation of augmented reality in teaching and learning. Majority of the studies in this area focuses on how this technology could impact students' performance and various skills including visualization skills. Hence, the purpose of this study was to examine the differences in students' visualization skills after utilizing Mobile Augmented Reality (MAR) and conventional learning in orthographic projection classroom. This study involved 60 students and was conducted in Universiti Teknologi Malaysia: 30 students in experimental group used MAR; 30 students in control group used conventional learning. In this study, mental rotation skills were measured using Purdue Spatial Visualization Test of Rotation (PSVT:R) due to its importance to ensure students understanding in orthographic projection. Results from this study showed a significant difference between students in both group where students in experimental group displayed a significantly higher level of visualization skills in terms of mental rotation skills compared to students in control group. At the end of their study, respondents were given a set of questionnaires to obtain their feedback on the use of MAR. Based on students' positive feedback on MAR, the result proved that it can be an effective spatial visualization tool. MAR is also practical to be used in classrooms since it has low production cost.
\end{abstract}

Keywords-Mobile Augmented Reality, Purdue Spatial Visualization Test of Rotation

\section{Introduction}

Teaching and learning are a fun process when it is carefully planned and executed in an exciting and creative manner. Apart from making it a fun process, teachers or educators can also grab the chance to help polish students' skills as well as deliver it effectively to ensure that students will fully understand and master the conceptual understanding of a learned topics.

The term augmented reality (AR) has been widely recognized by people all around the world. Augmented reality is defined as a technology that allows virtual elements 
being embedded into real environment that runs interactively in real time (Azuma, Baillot, Behringer, Feiner, Julier \& MacIntyre, 2001; Bower, Howe, McCredie, Robinson, Grover, 2014). It can also be defined as a system that supplements real world objects or environments with virtual elements. Augmented reality is a new technology that offers unique affordances to its users. It has been used in various field such as entertainments, medicine, military, engineering design and manufacturing (Berryman, 2012; Azuma, Baillot, Behringer, Feiner, Julier \& MacIntyre, 2001). Other than that, it is also been used in education field due to its interactive elements and its advantages towards teaching and learning. Augmented reality also has a huge impact on education in which it allows the visual interactivity of learning in a unique way (Yuen, Yaoyuneyong, Johnson, 2011; Saidin, Halim \& Yahaya, 2019), as well as presents the abstract concepts which cannot be done in two-dimensional format (Zagoranski \& Divjak, 2003).

There are several types of medium for this technology such as desktop and mobile. However, mobile Augmented Reality (MAR) has become a useful tool for educators and learners nowadays. The use of mobile technology in education due to the rapid development of this technology has brought major impact on students' learning and life (Ismail, Harun, Zakaria \& Salleh, 2017). Mobile technologies such as iPod and smartphones are one of the necessary gadgets that the students own nowadays. Teenagers especially used their own smartphones and tablets for variety of purposes (Sampson, Isaias, Ifenthaler \& Spector, 2012) such as entertainment and communication. Apart from social functions, mobile technology can also serve as a mean of supporting learning for students. The interesting facts about mobile learning can be seen in the following slogan which is "mobile learning revolutionizes the world of learning by allowing you to learn in every place and at any time of the day" (De Simone, 2016). The slogan means the use of smartphones or mobile devices as an instrument for learning purpose that can be use anytime and anywhere with an ideal of multitasking and ability to learn without losing any times. It is found that technology have great potential towards an increase in students' engagement and their understanding of the learning content itself. Thus, there is a need to adopt mobile technologies in learning due to its potential in attracting and motivating students during learning process ( $\mathrm{Yu}$, Lin, Ho \& Wang, 2015). The concept of MAR started to exists since mid-1990 in which AR was applied in truly mobile settings (Arth, Grasset, Gruber, Langlotz, Mulloni, Schmalstieg \& Wagner, 2015).

MAR has an advantage where it can be used in both formal and informal learning environment (Nincarean, Ali, Halim, \& Rahman, 2013). Among all the advantages of MAR that has been identified by researchers, one of its major advantages is its ability to enhance visualization skills (Hoe, Lee, Chen \& Chang, 2017). A study by Iulian Radu (2014) has listed all the educational affordances that MAR can offer. 
Table 1. Educational affordances for Mobile Augmented Reality

\begin{tabular}{|l|c|c|}
\hline \multirow{2}{*}{ Educational Affordance } & \multicolumn{2}{c|}{ Interactive, AR media } \\
\cline { 2 - 3 } & $\begin{array}{c}\text { Smartphone + } \\
\text { GPS-No Camera }\end{array}$ & $\begin{array}{c}\text { Smartphone + } \\
\text { GPS + Camera }\end{array}$ \\
\hline Alignment of multiple representations & & \\
\hline Spatial: Content is present in the same space as other related content & Strong & Strong \\
\hline $\begin{array}{l}\text { Temporal: Content is presented or adapted when relevant to student's } \\
\text { activity }\end{array}$ & Strong & Strong \\
\hline Support for embodiment & & \\
\hline $\begin{array}{l}\text { Student learns about spatial locations by moving body between physi- } \\
\text { cal locations }\end{array}$ & OK & Strong \\
\hline $\begin{array}{l}\text { Student learns about physical entities by mimicking the movement of } \\
\text { entities with their body }\end{array}$ & Weak & Weak \\
\hline Student learns about abstract entities by enacting embodied metaphors & Weak & Weak \\
\hline Directed Attention & & \\
\hline Media highlights specific content to scaffold student learning & Strong & Strong \\
\hline Interactive simulation & & \\
\hline Students can interact with visualized phenomena & Strong & Strong \\
\hline Media is accessible to large population & OK & OK \\
\hline Media facilitates collaboration & Weak & OK \\
\hline
\end{tabular}

(Source: Iulian Radu, 2014)

Visualization skills is the ability to mentally generate, manipulate and interprets three dimensional images (Martin-Gutierrez, Saorin, Contero, Alcañiz, Pérez-López \& Ortega, 2010). Another similar terms which is spatial visualization skills can be defined as "apprehending, encoding, and mentally manipulating three-dimensional spatial forms" (Carroll, 1993). It is one of the key components in order to succeed in Science, Technology, Engineering and Mathematics (STEM) field (Sorby, Veurink \& Streiner, 2018). It is said that high STEM achievers tend to have a very good visualization skill. Due to the absence of proper visualization skills training in pre-college level, it is often to see a large gap between freshman students in terms of their visualization skills (Sorby, Veurink \& Streiner, 2018). For engineering students, engineering drawing or technical drawing to be specific has a great influence towards their future career. However, learning engineering drawing specifically have some issue among students (Omar \& Ali, 2016). This is because most of students have difficulties in visualizing the objects especially in orthographic projection topics (Baronio, Motyl \& Paderno, 2016; Ali et al., 2017). This topic mainly involves visualizing objects while figuring the objects view from side views, front and top views. This topic requires students to use their visualization skills to enable them to see all the view perfectly and clearly as well as understand the concepts of engineering drawing clearly. According to Makgato and Khoza (2016), students often having difficulties when trying to understand sectional drawing as well as lack understanding on the two-dimensional and three-dimensional drawing. Other than that, students also have problems visualizing a rotated object.

Understanding of the concept when learning engineering drawing is important to help students to excel in their studies since there will be more complex courses in the future that requires them to use their visualization skills which will involves even 
more complex shapes and objects. Visualization skills also can help improve problem solving skills among engineering students (Ali \& Mokhtar, 2014; Stachel, 2016) because it is important for engineering students to have a good reasoning and visualization skills in order for them to survive in engineering programme. Other than that, mastering engineering drawing among engineers is a priority since it is a predictor for their career success (Ali, Omar \& Mokhtar, 2016; Shreeshail \& Koti, 2016). This is because, failure in reading or interpreting the drawing will cause issues in the designing and production process later on. According to Azodo (2016), having a good skill in producing, reading and interpreting engineering drawing will reduce the errors in the production process. Thus, it is important for teachers or lecturers to choose a right tool to help them see the views and understand the concept clearly instead of using trial and error method to solve the tasks given to them.

In this study, visualization skills among students when learning orthographic projection were examined. Additionally, students' feedback towards learning using Mobile Augmented Reality (MAR) were also studied. Our research questions were:

- Are there any improvements on students' visualization skills in experimental and control group?

- What is the difference in students' visualization skills between experimental and control group?

- What is the students' feedback towards learning using mobile augmented reality (MAR)?

\section{Development of Mobile Augmented Reality (MAR) Application}

The process of developing the MAR application uses 3D modelling software such as Autodesk 3D Studio Max to create and render 3D models, Unity3D software to create the AR platform and Android Studio as the official integrated development environment (IDE) for Google's Android operating system.

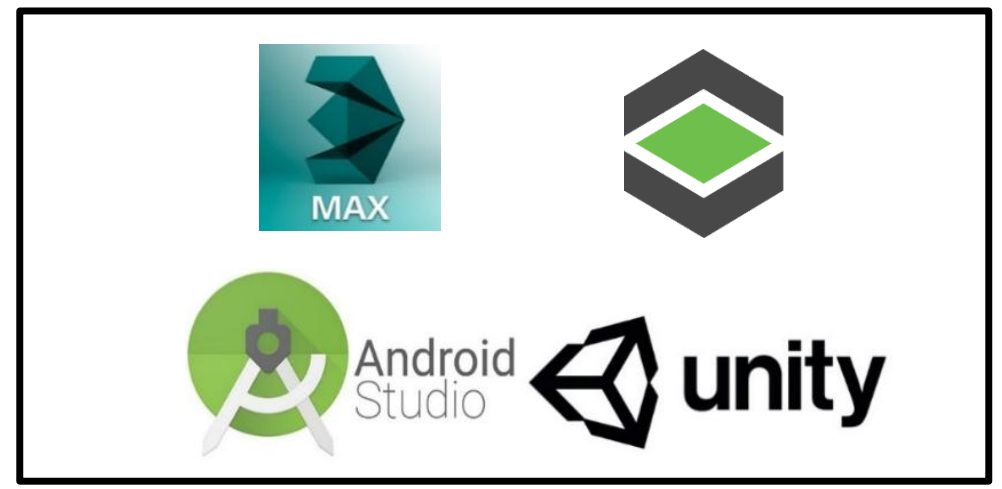

Fig. 1. Softwares used during development process 


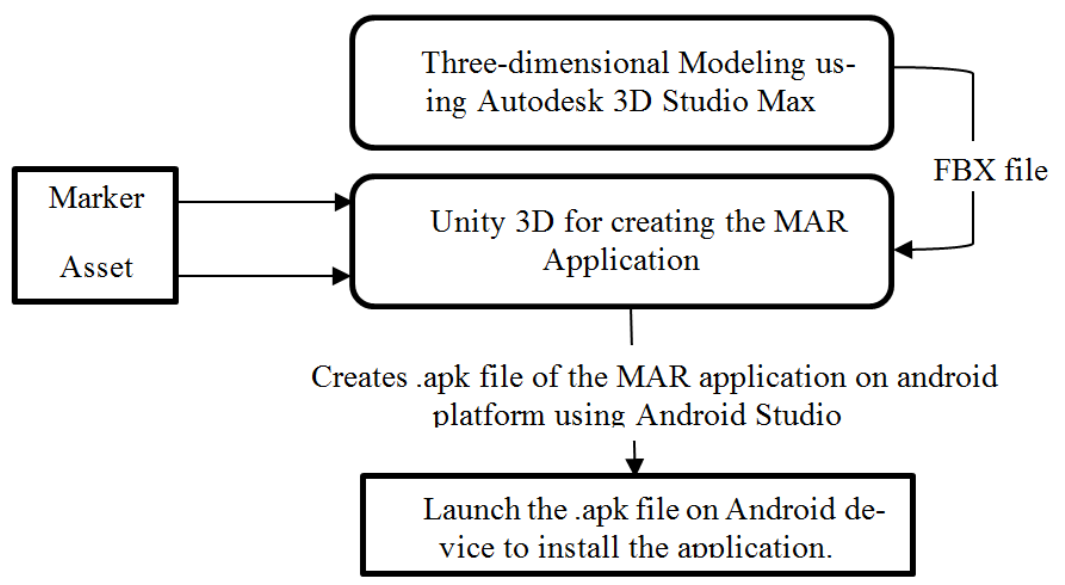

Fig. 2. Process of developing the MAR application

The justification for choosing three-dimensional model as the augmented objects or assets is made based on the major trends and also the effectiveness of learning using three-dimensional models towards improving spatial visualization skills. Table 2 shows the trends in the development of AR application in engineering education field.

Table 2. Trends in the development of augmented reality application in engineering education field

\begin{tabular}{|l|l|l|l|c|}
\hline \multicolumn{1}{|c|}{ Learning Tool } & Year & \multicolumn{1}{|c|}{ AR Approach } & \multicolumn{1}{c|}{ Aim } & Content \\
\hline AR-DEHAES & 2010 & $\begin{array}{l}\text { Desktop Augmented } \\
\text { Reality }\end{array}$ & Develop students' spatial skills & 3D Models \\
\hline L-ELIRA & 2011 & $\begin{array}{l}\text { Desktop Augmented } \\
\text { Reality }\end{array}$ & $\begin{array}{l}\text { Help students to learn sketch- } \\
\text { ing, designation and normaliza- } \\
\text { tion of mechanical elements }\end{array}$ & 3D Models \\
\hline AR Models & 2011 & $\begin{array}{l}\text { Desktop Augmented } \\
\text { Reality }\end{array}$ & $\begin{array}{l}\text { To compare between the use of } \\
\text { Tangible models and AR } \\
\text { models in helping students to } \\
\text { learn engineering drawing }\end{array}$ & 3D Models \\
\hline $\begin{array}{l}\text { Augmented Reality } \\
\text { Enhanced Exercise } \\
\text { Book }\end{array}$ & 2012 & $\begin{array}{l}\text { Desktop Augmented } \\
\text { Reality }\end{array}$ & $\begin{array}{l}\text { To improve visualization skills } \\
\text { of freshman engineering stu- } \\
\text { dents }\end{array}$ & 3D Models \\
\hline EducHolo & 2014 & $\begin{array}{l}\text { Mobile Augmented Reali- } \\
\text { ty }\end{array}$ & $\begin{array}{l}\text { Provide better perception of 3D } \\
\text { shape and to improve skills of } \\
\text { 2D orthographic views and } \\
\text { perspectives }\end{array}$ & 3D Models \\
\hline DiedricAR & 2016 & $\begin{array}{l}\text { Melps students learn descriptive } \\
\text { ty } \\
\text { geometry by interacting with } \\
\text { the didactical content and also a } \\
\text { potential Benefit towards } \\
\text { students' visualization skills }\end{array}$ & 3D Models \\
\hline
\end{tabular}

From table 1, it is shown that the trend for augmented reality application development are focusing more on three-dimensional model. This approach was chosen based 
on the aim of the application which is to increase perception and spatial visualization skills among students. Three-dimensional models can provide students with the accurate distance and volume of the objects learned (Weng, Hsu \& Yang, 2017). This is to overcome the weaknesses of using conventional method when presenting threedimensional spatial information. Figure 3 shows the three-dimensional models from the MAR application design for orthographic projection teaching and learning.

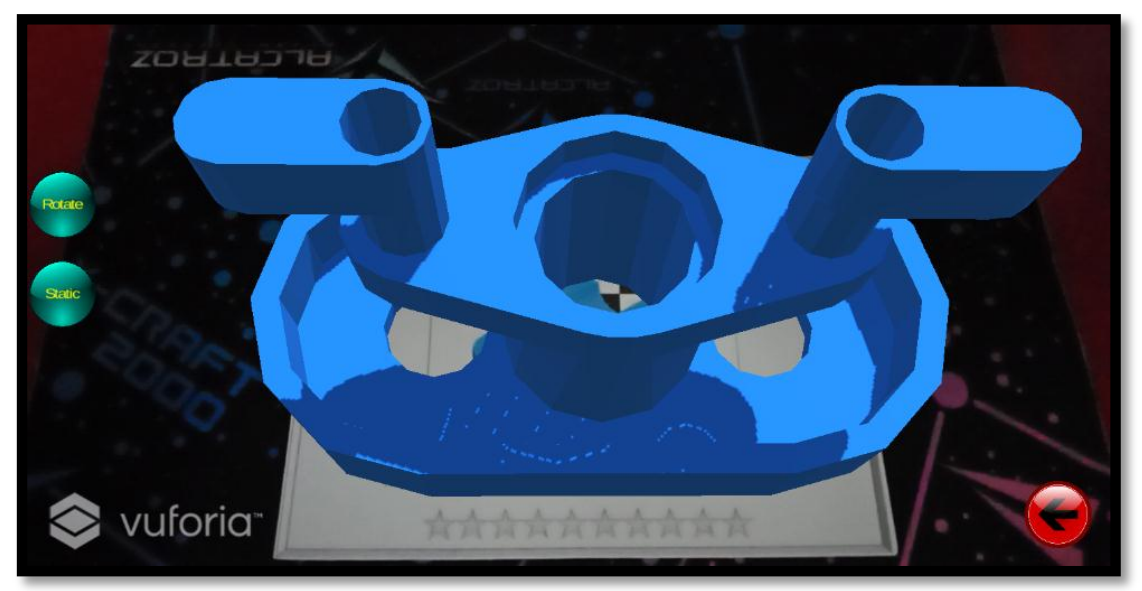

Fig. 3. Three-dimensional model from MAR application

The three-dimensional models were designed based on the two-dimensional exercises available in the orthographic projection syllabus for first-year engineering students. While using the application, students can manipulate the three-dimensional model as well as rotate the object to see all the views (ie: top, side and front). By implementing MAR instead of other technology such as VR (Mouse), students or users were 17.3 percent faster when completing their task (Krichenbauer et al., 2018). Hence, utilizing MAR during orthographic projection class is more efficient as well as can help student perform their task faster.

\section{$3 \quad$ Method}

\subsection{Participants}

Participants in this study consisted of 60 engineering students from Universiti Teknologi Malaysia enrolled in the Fundamental of Engineering Drawing course. A total of 30 students was selected as the experimental group meanwhile the other 30 students was selected as the control group. The experimental group used mobile augmented reality (MAR), and the control group used the conventional learning.

Both groups learned the orthographic projection topics which introduces them to the basic of engineering drawing. The orthographic projection topic is the topics that 
helps students to understand the steps to produce an engineering drawing manually which also involves the used of visualization skills especially mental rotation skills. The main goal of this class is to provide training among students to master or acquire the ability to study space, read and recognize the engineering drawings.

\subsection{Research design}

The independent variables in this study involves the learning materials used among students in orthographic projection course - mobile augmented reality and conventional learning. Dependent variables included the mental rotation test scores - administered to both groups after undergoing learning process.

Inferential analysis of paired sample t-test were used to find out the significant difference within the groups after the learning process. Other than that, an independent sample t-test was also used to find out the significant difference between experimental and control group. Finally, descriptive analysis of mean and percentage were used to analyze students' feedback towards using MAR in the classroom.

\subsection{Instrument}

Purdue Spatial Visualization Test on Rotation (PSVT:R): This instrument was developed by Guay (1976), with a purpose to measure mental rotation ability. Mental rotation ability has been a topic of interests among STEM researcher due to its potential relationship to academic performance. Mental rotation ability also is one of the abilities that plays a crucial role towards students' academic performance especially in engineering design skills. This instrument measures the level of mental rotation ability and normally can be classified into three level which is low, moderate and high level. Figure 4 shows the example of question in Purdue Spatial Visualization Test on Rotation.

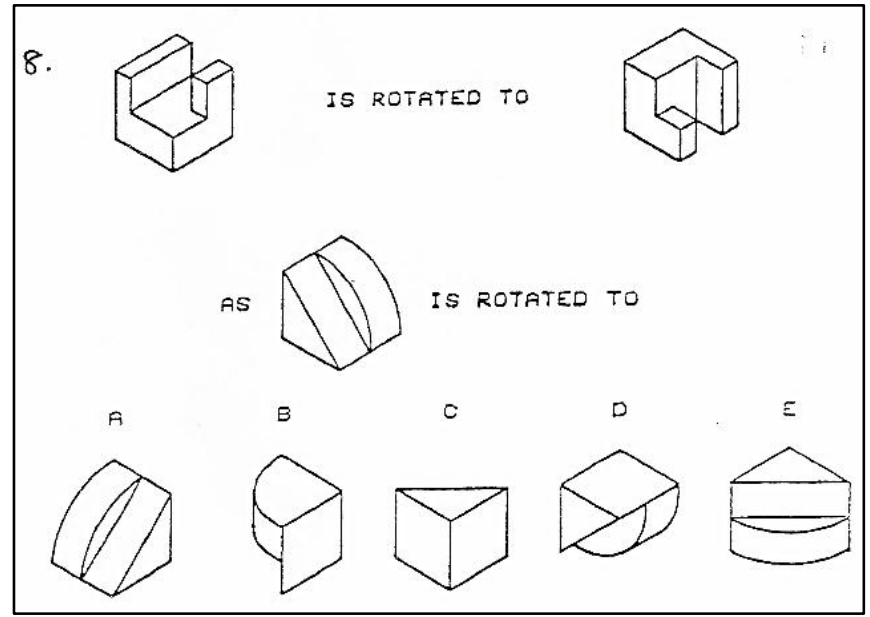

Fig. 4. Example of Purdue Spatial Visualization Test: Rotation Question 
Students' feedback questionnaire: This instrument was developed by researcher to identify students' feedback towards using MAR in orthographic projection classroom. This feedback is important for researcher in order to ensure that students' do enjoy learning using MAR during their learning process, as well as to determine students' perception towards the functionalities of MAR in improving their visualization skills through their experiences of using MAR.

\section{$4 \quad$ Results}

\subsection{Improvements on students' visualization skills in experimental and control group}

This study aims to determine the effect of using MAR application in enhancing students' spatial visualization skills. Table 3 shows the differences between mean scores of PSVT:R pre-test and post-test.

Table 3. The differences between mean scores of PSVT: R pre-test and post-test

Paired samples statistics

\begin{tabular}{|l|c|c|c|c|}
\hline & Mean & N & Std. Deviation & Std. Error Mean \\
\hline PSVT: R PRE & 58.6676 & 30 & 25.15135 & 4.5920 \\
\hline PSVT: R POST & 82.4444 & 30 & 15.10884 & 2.7584 \\
\hline
\end{tabular}

Paired samples test

\begin{tabular}{|c|c|c|c|c|c|c|c|c|}
\hline & \multicolumn{5}{|c|}{ Paired Differences } & \multirow{3}{*}{$\mathbf{t}$} & \multirow{3}{*}{ df } & \multirow{3}{*}{$\begin{array}{l}\text { Sig. }(2- \\
\text { tailed) }\end{array}$} \\
\hline & \multirow[t]{2}{*}{ Mean } & \multirow[t]{2}{*}{ Std. Deviation } & \multirow{2}{*}{$\begin{array}{c}\text { Std. Error } \\
\text { Mean }\end{array}$} & \multicolumn{2}{|c|}{$\begin{array}{l}\text { 95\% Confidence Interval } \\
\text { of the Difference }\end{array}$} & & & \\
\hline & & & & Lower & Upper & & & \\
\hline $\begin{array}{l}\text { PSVT: R PRE- } \\
\text { POST }\end{array}$ & -23.7776 & 29.4567 & 5.3835 & -34.7882 & -12.7671 & -4.417 & 29 & .000 \\
\hline
\end{tabular}

The findings indicate a significant difference in students' mental rotation skills after they undergo the orthographic projection teaching and learning process using MAR application. The paired sample test showed that there is a significant increase in the pre-test and post-test of PSVT:R $(M=-23.7776, S D=29.4567)$ where the increase is significant at $\mathrm{t}(29)=-4.417, \mathrm{p}<0.05$. This finding shows that AREDApps is proven to be an effective tool in enhancing students' mental rotation skills. 
Table 4. The differences between mean scores of PSVT:R pre-test and post-test for the control group

Paired samples statistics

\begin{tabular}{|l|l|l|l|l|}
\hline & \multicolumn{1}{|c|}{ Mean } & \multicolumn{1}{c|}{ N } & \multicolumn{1}{c|}{ Std. Deviation } & \multicolumn{1}{c|}{ Std. Error Mean } \\
\hline PSVT: R PRE & 58.8893 & 30 & 23.5592 & 4.3013 \\
\hline PSVT: R POST & 59.7787 & 30 & 22.0402 & 4.0239 \\
\hline
\end{tabular}

Paired samples test

\begin{tabular}{|c|c|c|c|c|c|c|c|c|}
\hline & \multicolumn{5}{|c|}{ Paired Differences } & \multirow{3}{*}{$\mathbf{t}$} & \multirow{3}{*}{ df } & \multirow{3}{*}{$\begin{array}{l}\text { Sig. (2- } \\
\text { tailed) }\end{array}$} \\
\hline & \multirow[t]{2}{*}{ Mean } & \multirow{2}{*}{$\begin{array}{l}\text { Std. Devia- } \\
\quad \text { tion }\end{array}$} & \multirow{2}{*}{$\begin{array}{c}\text { Std. } \\
\text { Error } \\
\text { Mean }\end{array}$} & \multicolumn{2}{|c|}{$\begin{array}{c}95 \% \text { Confidence Interval } \\
\text { of the Difference }\end{array}$} & & & \\
\hline & & & & Lower & Upper & & & \\
\hline $\begin{array}{l}\text { PSVT: R PRE- } \\
\text { POST }\end{array}$ & -.8893 & 31.9831 & 5.8393 & -12.8320 & 11.0533 & -.152 & 29 & .880 \\
\hline
\end{tabular}

\subsection{Differences in students' visualization skills between experimental and control group}

Gain scores for experimental group is relatively higher than the gain scores obtained from the control group (see Table 5). Results shows that experimental group which undergoes teaching and learning using MAR exhibit higher gain scores $(\mathrm{GS}=23.777, \mathrm{SD}=10.043)$ when compare to the control group which undergoes conventional learning $(\mathrm{GS}=0.889, \mathrm{SD}=1.518)$.

Table 5. Gain scores of PSVT: R test according to the intervention group

\begin{tabular}{|l|c|c|c|}
\hline \multicolumn{1}{|c|}{ Intervention Group } & $\mathbf{N}$ & Gain Scores (GS) & Std. Deviation \\
\hline Experimental & 30 & 23.777 & 10.043 \\
\hline Control & 30 & 0.889 & 1.518 \\
\hline
\end{tabular}

An independent sample test was conducted to compare the students visualization skills in experimental group and control group after both group have completed orthographic projection learning using MAR and conventional learning. Table 6 shows the independent sample test for PSVT:R test gain scores between experimental and control group after they have completed the orthographic projection topic learning. The results indicate that the independent sample test shows a large significant value of $.801(\mathrm{~F}=.064)$. Hence, the null hypotheses which stated that the two population variances were equal was accepted and were used to identify the significant differences. Furthermore, the value of t-test with equal variances was -4.646 at degrees of freedom df equal to 58. Based on the findings, it indicates that the null hypotheses are accepted as the value of $p$ is smaller than $\alpha$ value $(p=.000<0.05)$. Thus, the result shows that there is significant difference in the mean score of mentally rotating $3 \mathrm{D}$ objects skills between the respondents in experimental and control group. 
Table 6. Independent sample test for PSVT: R test gain scores

\begin{tabular}{|l|l|c|c|c|c|c|c|}
\hline \multicolumn{2}{|c|}{} & \multicolumn{2}{|c|}{$\begin{array}{c}\text { Levene's test for } \\
\text { equality of variances }\end{array}$} & \multicolumn{4}{|c|}{ t-test for Equality of Means } \\
\cline { 3 - 8 } & $\boldsymbol{F}$ & Sig. & $\boldsymbol{t}$ & $\boldsymbol{d f}$ & Sig. (2-tailed) & $\begin{array}{c}\text { Mean Differ- } \\
\text { ence }\end{array}$ \\
\hline $\begin{array}{l}\text { PSVT: R } \\
\text { POST }\end{array}$ & $\begin{array}{l}\text { Equal variances } \\
\text { assumed }\end{array}$ & .064 & .801 & 4.646 & 58 & .000 & 22.66567 \\
\cline { 2 - 8 } & $\begin{array}{l}\text { Equal variances } \\
\text { not assumed }\end{array}$ & & & 4.646 & 51.325 & .000 & 22.66567 \\
\hline
\end{tabular}

\subsection{Students' feedback towards the use of MAR in orthographic projection topic}

Other than that, this study also attempts to identify students' perception towards using MAR application for orthographic projection topic. Figure 5 shows students' feedback on using MAR application.

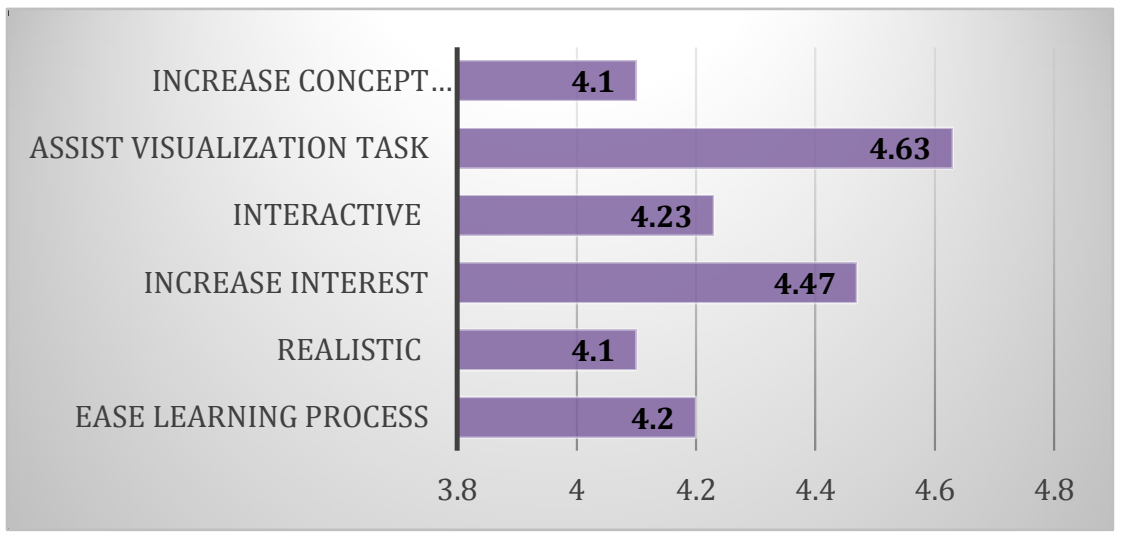

Fig. 5. Students' Feedback on using MAR application for orthographic projection topic

Among all the feedback, it is shown that the statement where MAR application for orthographic projection topic can assists students in the visualization tasks showed the highest positive feedback among all the statements. This is because the nature of MAR application which enable students to actively manipulate virtual objects in real environment had contributed to this finding. Other than that, it is also shown from the feedback that learning using MAR application increases students' interest towards learning as well as ease learning process.

\section{$5 \quad$ Discussions}

Utilization of augmented reality application to enhance perception and to train spatial visualization skills among students has been stated in one of the five directions of augmented reality in education field (Yuen, Yauyuneyong \& Johnson, 2011). This can 
be seen from the result of PSVT:R in this study where significant differences were observed from the pre-test and post-test scores. Thus, it can be proven that augmented reality have the ability to enhance spatial visualization skills especially mental rotation skills among students during teaching and learning. This is by permitting students to have active interaction with the three-dimensional virtual objects (Liarokapis et al., 2004). Results for the independent sample t-test for PSVT:R between students in experimental and control group also shows that there is significant difference between these two group. Students in experimental group shows a significantly higher gain scores when compare to students in control group.

By integrating technology in the classroom, it could help enhance and supplement the components of an instructional model (Bates and Poole, 2003). This is also supported by recent work by Shirazi and Behzadan (2013) especially in engineering and science field. Thus, by implementing MAR in orthographic projection lessons, students will be able to enhance their understanding with the additional information that can be delivered using the technology.

Based on findings on figure 3, six aspects have been studied to find out students' perception on each aspect. Among all the aspects studied in this section, assist visualization tasks receive the highest scores. This finding proves that apart from the data that shows increase in visualization test scores, students also find that this application is helpful in solving their visualization task while learning. This finding is parallel with Dunser. Steinbugl, Kaufmann and Glück (2006) where the use of threedimensional virtual model in their research had received positive feedback from the students regarding the aspects of assisting them in solving visualization tasks.

Next, students also give positive feedback on the ability of this application in increasing their interests to engage in teaching and learning process. This is due to the implementation of constructivism theory in the development of this application that allows students to be an active learner. Students tend to be more engage with learning when they get to manipulate and apply knowledge as well as their skills without being controlled too much by their teacher (Gül, Williams \& Gu, 2012). Thus, learning can be a fun process and students will be able to construct meaning from the knowledge they gained. Other than that, interactivity is also one of the key aspects that should be taken seriously when designing a teaching and learning aids. This statement is supported by Sorden (2012) where learning using interactive multimedia allows students to learn more deeply. Other than that, it is well known that technology if used properly, could serve as an opportunity to engage students' learning. This is due to the fact that students will feel more motivated and excited when new methods or approach is being used in the classroom instead of using the same approach in every teaching and learning sessions.

However, to maximize the advantages of this technology towards achieving the main goal of developing it, there should be several aspects that need to be follow and the product must achieve certain qualities. This is to enable students to easily understand and use the application. This is where the use of theories and models to support the process plays the role. Integration of theories and models is crucial in order to identify the most effective approach being used during the production and development process. 


\section{Conclusions and Future Research}

Understanding orthographic projection is proven to be difficult for some students especially among those with low visualization skills. Teaching and learning process should be maximize and new technology should be utilize effectively to ensure all students received fair amount of knowledge transfer. Other than that, it is also to ensure an increase in students' performance and skills. Augmented reality specifically has advantages towards increasing students' visualization skills. This study has showed that MAR is suitable to be used as spatial visualization training tools as well as increase students' interest towards learning complex course. This is due to the significant difference in the mental rotation test that researcher has distributed to the respondent before and after the teaching and learning process using MAR. The authors are currently working on expanding the application of this MAR application on the whole Fundamental of Engineering Drawing subject. This is to ensure that all syllabus will be able to be covered as it will help engineering drawing educators to save more time in preparing the teaching aid for the classroom, and instead they can focus more time on building understanding of the concept itself among the students. As a conclusion, learning using MAR is effective towards enhancing the quality of teaching and learning process and help maximize students' learning experience.

\section{$7 \quad$ Acknowledgement}

The authors would like to thank Universiti Teknologi Malaysia (UTM) and Ministry of Higher Education (MOHE) Malaysia, for their support. This study was supported by a grant from the Tier 1 Grant Scheme (Vot. No. Q.J130000.2531.19H10).

\section{$8 \quad$ References}

[1] Arth C, Grasset R, Gruber L, Langlotz T, Mulloni A, Schmalstieg D, Wagner D (2015) The history of mobile augmented reality. Developments in Mobile AR over the last almost 50 years. Technical Report ICG-TR-2015-001. Inst. for Computer Graphics and Vision. Graz University of Technology, Austria

[2] Azodo, A. P. (2016). Attitude of engineering students towards engineering drawing: A case study. Int. J. Res. Studies in Edu, 6(1), 71-84.

[3] Azuma, R., Baillot, Y., Behringer, R., Feiner, S., Julier, S., \& MacIntyre, B. (2001). Recent advances in augmented reality. IEEE computer graphics and applications, 21(6), 3447. https://doi.org/10.1109/38.963459

[4] Bacca, J., Baldiris, S., Fabregat, R., \& Graf, S. (2014). Augmented reality trends in education: a systematic review of research and applications. Journal of Educational Technology \& Society, 17(4), 133.

[5] Baronio, G., Motyl, B., \& Paderno, D. (2016). Technical drawing learning tool-level 2: An interactive self-learning tool for teaching manufacturing dimensioning. Computer Applications in Engineering Education, 24(4), 519-528. https://doi.org/10.1002/cae.21728

[6] Berryman, D. R. (2012). Augmented reality: a review. Medical reference services quarterly, 31(2), 212-218. https://doi.org/10.1080/02763869.2012.670604 
[7] Bower, M., Howe, C., McCredie, N., Robinson, A., \& Grover, D. (2014). Augmented Reality in education-cases, places and potentials. Educational Media International, 51(1), 115. https://doi.org/10.1080/09523987.2014.889400

[8] Cuendet, S., Bonnard, Q., Do-Lenh, S., \& Dillenbourg, P. (2013). Designing augmented reality for the classroom. Computers \& Education, 68, 557-569. https://doi.org/10.1016/j. compedu.2013.02.015

[9] De Simone, G. C. (2016). Mobile Learning: Extreme Outcomes of" Everywhere, Anytime". International Association for Development of the Information Society.

[10] Dünser, A., Steinbügl, K., Kaufmann, H., \& Glück, J. (2006, July). Virtual and augmented reality as spatial ability training tools. In Proceedings of the 7th ACM SIGCHI New Zealand chapter's international conference on Computer-human interaction: design centered HCI (pp. 125-132). ACM. https://doi.org/10.1145/1152760.1152776

[11] Guay, R. B. (1976). Purdue spatial visualization test. West Lafayette, IN: Purdue Research Foundation.

[12] Gül, L. F., Williams, A., \& Gu, N. (2012). Constructivist learning theory in virtual design studios. Computational Design Methods and Technologies: Applications in CAD, CAM and CAE Education, 139-162. https://doi.org/10.4018/978-1-61350-180-1.ch009

[13] Hoe, Z. Y., Lee, I. J., Chen, C. H., \& Chang, K. P. (2017). Using an augmented realitybased training system to promote spatial visualization ability for the elderly. Universal Access in the Information Society, 1-16. https://doi.org/10.1007/s10209-017-0597-x

[14] Krichenbauer, M., Yamamoto, G., Taketom, T., Sandor, C., \& Kato, H. (2018). Augmented reality versus virtual reality for $3 \mathrm{~d}$ object manipulation. IEEE transactions on visualization and computer graphics, 24(2), 1038-1048. https://doi.org/10.1109/tvcg.2017.2658570

[15] Liarokapis, F., Mourkoussis, N., White, M., Darcy, J., Sifniotis, M., Petridis, P., ... \& Lister, P. F. (2004). Web3D and augmented reality to support engineering education. World Transactions on Engineering and Technology Education, 3(1), 11-14.

[16] Liarokapis, F., Petridis, P., Lister, P. F., \& White, M. (2002). Multimedia augmented reality interface for e-learning (MARIE). World Transactions on Engineering and Technology Education, 1(2), 173-176.

[17] Liarokapis, F., Petridis, P., Lister, P. F., \& White, M. (2002). Multimedia augmented reality interface for e-learning (MARIE). World Transactions on Engineering and Technology Education, 1(2), 173-176.

[18] Makgato, M., \& Khoza, S. D. (2016). Difficulties of Student Teachers in the Engineering Graphics and Design Course at a South African University: Snapshot on sectional drawing. Eurasia Journal of Mathematics, Science \& Technology Education, 12(4). https://doi.org/ 10.12973/eurasia.2016.1220a

[19] Martín-Gutiérrez, J., Saorín, J. L., Contero, M., Alcañiz, M., Pérez-López, D. C., \& Ortega, M. (2010). Design and validation of an augmented book for spatial abilities development in engineering students. Computers \& Graphics, 34(1), 77-91. https://doi.org/10.10 16/j.cag.2009.11.003

[20] Nincarean, D., Alia, M. B., Halim, N. D. A., \& Rahman, M. H. A. (2013). Mobile augmented reality: The potential for education. Procedia-social and behavioral sciences, 103, 657-664. https://doi.org/10.1016/j.sbspro.2013.10.385

[21] Sampson, D. G., Isaias, P., Ifenthaler, D. and Spector, M. (Eds.). 2012. Ubiquitous and mobile learning in the digital age. Springer Science \& Business Media, New York, USA. https://doi.org/10.1007/978-1-4614-3329-3

[22] Shreeshail, M. L., \& Koti, C. M. (2016). Augmenting the out of Classroom Learning of Machine Drawing Laboratory Course. Journal of Engineering Education Transformations, 29(4), 37-41. https://doi.org/10.16920/jeet/2016/v0i0/85608 
[23] Sorby, S., Veurink, N., \& Streiner, S. (2018). Does spatial skills instruction improve STEM outcomes? The answer is 'yes'. Learning and Individual Differences, 67, 209-222. https://doi.org/10.1016/j.lindif.2018.09.001

[24] Sorden, S. D. (2012). The cognitive theory of multimedia learning. Handbook of educational theories, 1 .

[25] Stachel, H. (2016). A Strategy to Train Spatial Ability. In International Distance Education Conference.

[26] Weng, T. S., Hsu, M. H., \& Yang, D. C. (2017). A Study investigating the use of 3D computer animations of trigonometric functions to enhance spatial perception ability. International Journal of Information and Education Technology, 7(1), 23. https://doi. org/10.18178/ijiet.2017.7.1.836

[27] Yu, W. C. W., Lin, C. C., Ho, M. H., \& Wang, J. (2015). Technology Facilitated PBL Pedagogy and Its Impact on Nursing Students' Academic Achievement and Critical Thinking Dispositions. Turkish Online Journal of Educational Technology-TOJET, 14(1), 97-107.

[28] Yuen, S. C. Y., Yaoyuneyong, G., \& Johnson, E. (2011). Augmented reality: An overview and five directions for AR in education. Journal of Educational Technology Development and Exchange (JETDE), 4(1), 11. https://doi.org/10.18785/jetde.0401.10

[29] Zagoranski S \& Divjak S (2003) Use of augmented reality in education. In: EUROCON 2003, Ljubljana, Slovenia, pp 339-342. https://doi.org/10.1109/eurcon.2003.1248213

[30] Omar, M. \& Ali, D.F. (2016). The level of visualization skills among engineering student in universiti teknologi Malaysia. Man in India, 96(1-2), 427-431

[31] Ali, D.F., Omar, M., Mokhtar, M., Ali, M., Suhairom, Abd Halim, N.D., Shukor, N.A. \& Abdullah, Z. (2017). Enhancing students' mental rotation skills in engineering drawing by using virtual learning environment. Man in India, 97 (17), 161-170

[32] Ali, D.F., Omar, M. \& Mokhtar, M. (2016). Spatial visualization ability among engineering students in Malaysia. Man in India,

[33] Ali, D.F. \& Mokhtar, M. (2014). Visualization skills among Universiti Teknologi Malaysia student. ISTMET 2014 - 1st International Symposium on Technology Management and Emerging Technologies, Proceedings 6936494, pp. 139-142. https://doi.org/10.1109/ist met.2014.6936494

[34] Saidin, N. F., Halim, N. D. A., \& Yahaya, N. (2019). Framework For Developing A Mobile Augmented Reality For Learning Chemical Bonds. International Journal Of Interactive Mobile Technologies (Ijim), Vol 13, No 07 (Pp 54-68). https://doi.org/10.3991/ijim.v13 $\underline{\mathrm{i} 07.10750}$

\section{Authors}

Marlissa Omar, Dayana Farzeeha Ali, Mahani Mokhtar, Norasykin Mohd Zaid, Hanifah Jambari and Nor Hasniza Ibrahim all work for School of Education as Faculty of Social Science and Humanities in Universiti Teknologi Malaysia

Article submitted 2019-06-06. Resubmitted 2019-08-12. Final acceptance 2019-08-15. Final version published as submitted by the authors. 